\title{
Empiema do Coto Ureteral após Heminefrectomia
}

\section{Ureteral Stump Empyema after Heminephrectomy}

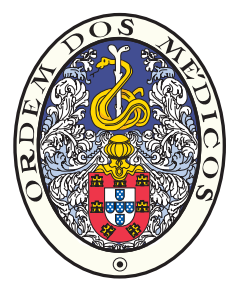

Joana PEREIRA ${ }^{1}$, Armando REIS $^{2}$, Ribeiro de CASTRO ${ }^{1}$

Acta Med Port 2014 May-Jun;27(3):404-404

Palavras-chave: Empiema; Complicações Pós-Operatórias; Doenças Ureterais; Nefrectomia.

Keywords: Empyema; Postoperative Complications; Ureteral Diseases; Nephrectomy.
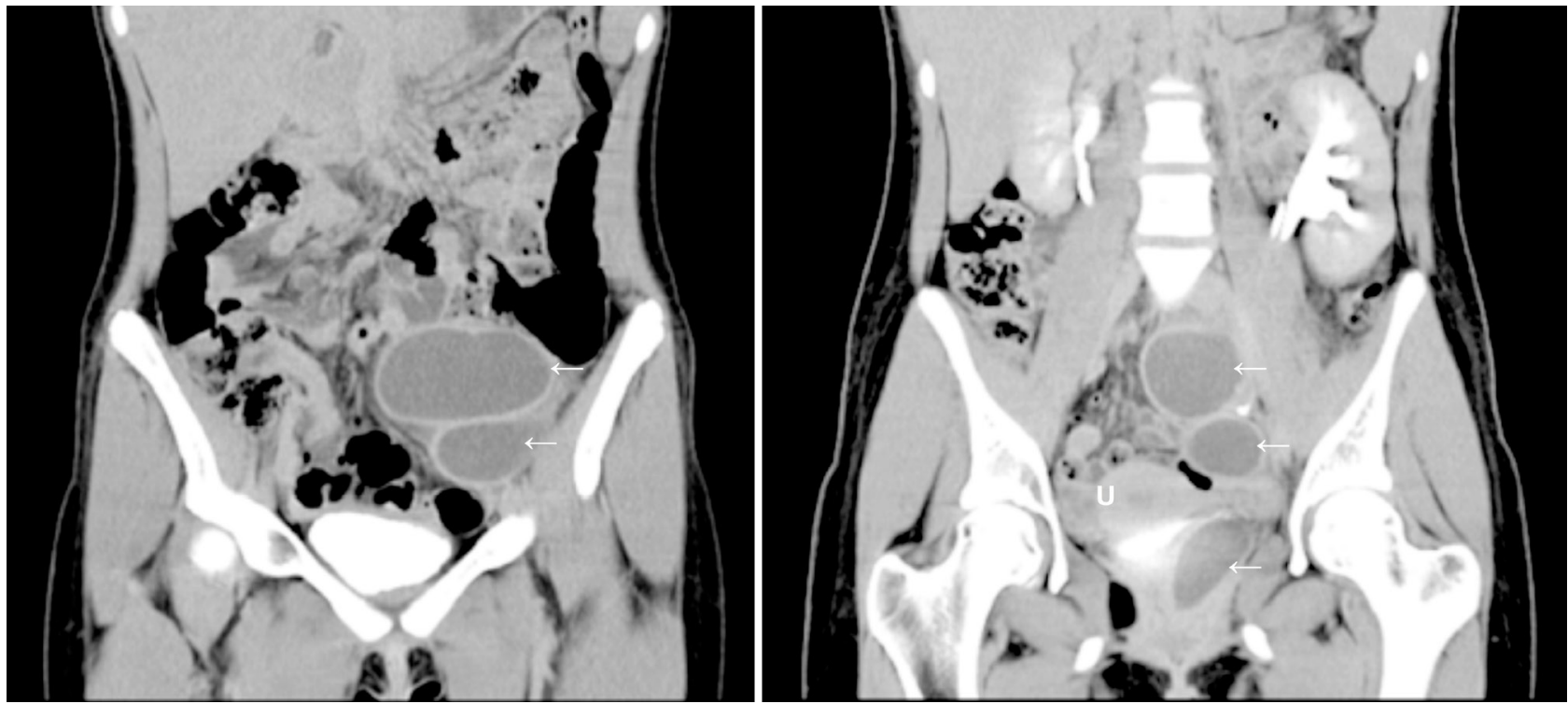

Figuras 1 e 2 - Empiema de coto ureteral (coto ureteral - setas brancas, U - útero) após heminefrectomia e ureterectomia parcial, em doente com triplicidade ureteral esquerda

Uma adolescente de 15 anos foi observada no Serviço de Urgência por desconforto suprapúbico e febre. Tinha antecedentes de triplicidade uretral esquerda e nefrectomia polar superior, cinco anos antes. Ao exame objectivo apresentava dor à palpação profunda da fossa ilíaca esquerda, sem sinais de irritação peritoneal. Analiticamente com PCR elevada $(98,4 \mathrm{mg} / \mathrm{L})$ e sedimento urinário com 642 leucócitos/campo. Para esclarecimento de formação hipoecogénea identificada em ecografia realizou tomografia computorizada abdomino-pélvica que revelou formação tubular serpinginosa ao longo da vertente esquerda da escavação pélvica, com parede ligeiramente espessada e conteúdo hipodenso, de dimensões máximas de 42 por 135 milímetros. Esta estrutura correspondia ao coto ureteral, com sinais inflamatórios. Foi submetida a laparoscopia exploradora e excisão de coto ureteral. O empiema do coto ureteral é uma entidade rara, ocorrendo em cerca de $1 \%$ dos doentes submetidos a nefrectomia/heminefrectomia e ureterectomia parcial. ${ }^{1,2} \mathrm{O}$ tratamento definitivo é a excisão do ureter remanescente. . $^{3,4}$

Nota: Apresentado sob a forma de vídeo em Junho de 2012 no $5^{\circ}$ Congresso Nacional de Cirurgia Minimamente Invasiva / Congresso Anual de Cirurgia Pediátrica, Porto.

\section{REFERÊNCIAS}

1. Labanaris AP, Zugor V, Smiszek R, Nützel R, Kühn R. Empyema of the ureteral stump. An unusual complication following nephrectomy. ScientificWorldJournal. 2010;10:380-3.

2. De Caluwé D, Chertin B, Puri P. Long-term outcome of the retained ureteral stump after lower pole heminephrectomy in duplex kidneys. Eur Urol. 2002;42:63-6.

3. Labairu-Huerta L, Burguete-Moriones A, Zabalza-Unzué J, Grasa-Lanau V. Ureteral stump empyema. A report of a case and review of the literature. Actas Urol Esp. 2010;34:909-11.

4. Khan AM, Jacob S. Management of symptomatic ureteric stumps laparoscopically. Asian J Androl. 2001;3:147-50.

1. Serviço de Cirurgia Pediátrica. Centro Hospitalar do Porto. Porto. Portugal.

Recebido: 27 de Julho de 2013 - Aceite: 20 de Janeiro de 2014 | Copyright (c) Ordem dos Médicos 2014 


\section{Empiema do Coto Ureteral após Heminefrectomia \\ Acta Med Port 2014:27:404-404}

Publicado pela Acta Médica Portuguesa, a Revista Científica da Ordem dos Médicos

Av. Almirante Gago Coutinho, 151

1749-084 Lisboa, Portugal.

Tel: +351218428215

E-mail: submissao@actamedicaportuguesa.com

www.actamedicaportuguesa.com

ISSN:0870-399X | e-ISSN: 1646-0758

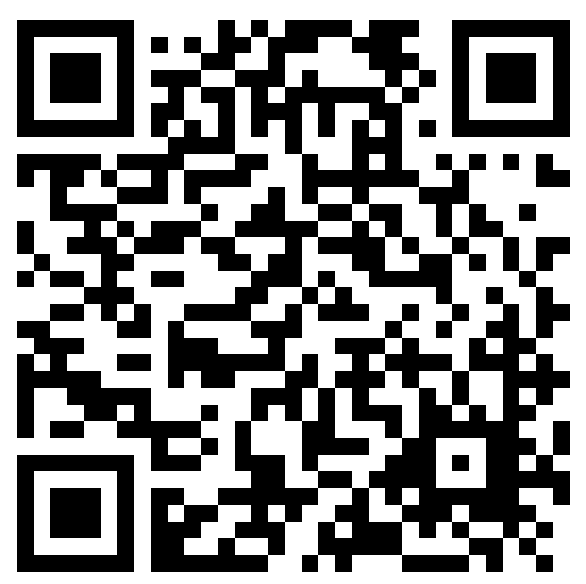

